DOI: $10.1515 / \mathrm{rrlm}-2016-0034$

\title{
NIPAL4 mutation c.527C $>A$ identified in Romanian patients with autosomal recessive congenital ichthyosis
}

\section{Mutația c.527C $>$ A în gena NIPAL4 identificată la pacienți români cu ihtioză congenitală autozomal recesivă}

\author{
Dalila Maier ${ }^{1}$, Adrian Florea ${ }^{2}$, Mariana Cornelia Tilinca ${ }^{3, *}$, Ancuța Zazgyva ${ }^{3}$, \\ Rodica Cosgarea ${ }^{1}$
}

'Dermatology Department, "Iuliu Haţieganu” University of Medicine and Pharmacy, Cluj-Napoca, Romania, ${ }^{2}$ Department of Cell and Molecular Biology, "Iuliu Hatieganu” University of Medicine and Pharmacy, Cluj-Napoca, Romania, ${ }^{3}$ Department of Cellular and Molecular Biology, University of Medicine and Pharmacy Tîrgu Mures, Romania

\begin{abstract}
Introduction: Autosomal recessive congenital ichthyosis is a non-syndromic ichthyosis, with a genetic background of mutations in 9 genes. This case series presents clinical and paraclinical particularities of 3 Romanian ARCI patients with NIPAL4 mutation c.527C $>$ A.

Material and methods: Three Caucasian patients were investigated, two sisters and an unrelated female patient, aged 47, 49, and 42 respectively. Skin anomalies were recorded and documented photographically; peripheral blood samples were harvested for DNA extraction and gene analysis. Skin biopsies were used for histological assessment, electron microscopy, and evaluation of in situ transglutaminase 1 activity.

Results: All patients presented with generalized ichthyosis, palmoplantar keratoderma, normal hair shafts, and significant oral manifestations. Natural evolution was relatively stable in all cases, without phenotype changing. Medical treatment with retinoids in patients 1 and 2 resulted in normalisation of the skin condition.

Histological samples showed hyperkeratosis, acanthosisand perivascular inflammatory infiltrates in the dermis. Positive findings of transglutaminase 1 in situ activity excluded TGM1 deficiency. Direct sequencing of amplicons revealed one homozygous mutation in exon 4, a c.527C $>$ A missense mutation.

Conclusions: This is the first report of the hotspot mutation NIPAL4 c.527C >A in Romanian autosomal recessive congenital ichthyosis patients. The phenotype was similar to that reported in the literature, while transglutaminase 1 activity in situ assay detected differences in enzyme distribution between patients bearing the same mutation but different phenotypes. Based on the current data, NIPAL4 mutations are more frequent than TGM1 mutations in Romanian patients with autosomal recessive congenital ichthyosis.
\end{abstract}

Keywords: autosomal recessive congenital ichthyosis;NIPAL4 mutation; transglutaminase 1; electron microscopy.

\footnotetext{
* Corresponding author: Mariana Cornelia Tilinca, Department of Cellular and Molecular Biology, University of Medicine and Pharmacy Tîrgu Mures, Gh. Marinescu Street 38, Tîrgu Mures, Romania, e-mail: mariana.tilinca@umftgm.ro
} 


\section{Rezumat}

Introducere: Ihtioza congenitală autozomal recesivă este o ihtioză nonsindromică, cu posibile mutații în 9 gene. Lucrarea prezintă particularitățile clinice și paraclinice a 3 pacienți români cu mutația c.527C $>$ A. a genei NIPAL4. Material si metodă: Studiul a inclus 2 surori și o pacientă neînrudită în vârstă de 47, 49 și respectiv 42 de ani. Modificările tegumentare au fost înregistrate și documentate fotografic; s-au recoltat probe de sânge periferic pentru extracția ADN și analiza genetică. Biopsiile cutanate au fost utilizate pentru evaluări histologice, de microscopie electronică, și evaluarea activității în situ a transglutaminazei 1 .

Rezultate: Toți pacienții prezentau ihtioză generalizată, keratodermie palmo-plantară, foliculi piloși normali și manifestări orale semnificative. Evoluția naturală a bolii a fost relativ stabilă, fără modificări fenotipice, iar la două paciente tratamentul medicamentos cu retinoizi a produs normalizarea modificărilor cutanate.

Histologic s-au evidențiat hiperkeratoză, acantoză și infiltrate inflamatorii perivasculare în derm. Rezultatele pozitive ale activității in situ a transglutaminazei 1 au exclus prezența unei mutații a TGM1. Secvențierea directă a ampliconilor a demonstrat o mutație homozigotă în exonul 4, o mutație cu sens greșit c.527C $>A$.

Concluzii: Acesta este primul raport asupra mutației "hotspot" c.527C $>$ A a genei NIPAL4 la pacienți români cu ihtioză congenitală autozomal recesivă. Deși fenotipul a fost asemănător celor descrise în literatură, evaluarea activității in situ a transglutaminazei 1 a demonstrat diferențe în distribuția enzimei la pacienți cu aceeași mutație dar fenotip diferit. Datele actuale susțin faptul că mutațiile NIPAL4 sunt mai frecvente decât cele ale TGM1 la pacienții români cu această afecțiune.

Cuvinte cheie: ihtioză congenitală autozomal recesivă; mutație NIPAL4; transglutaminază 1; electronomicroscopie.

Received: 07 $7^{\text {th }}$ June 2016; Accepted: 21 $1^{\text {th }}$ September 2016; Published: $26^{\text {th }}$ September 2016.

\section{Introduction}

Autosomal recessive congenital ichthyosis (ARCI) is part of the rare Mendelian disorders of cornification with a prevalence of $7: 1,000,000(1)$, and skin damage consisting of severe generalized scaling and hyperkeratosis, greatly impacting quality of life $(1,2)$. It is considered a non-syndromic ichthyosis, as the genetic defect induces phenotypic expressions confined to the tegument, and includes three major clinical entities: lamellar ichthyosis (LI), congenital erythroderma (CIE), and harlequin ichthyosis, with minor variants thereof (2).

The two main clinical phenotypes: LI with large, dark grey/ brownish thick scales, and CIE with generalized severe whitish scaling and erythema without blister formation (previously non-bullous ichthyosiform erythroderma) have been recognized as distinct autosomal congenital ichthyosis since the 1980s (3). However, because of the high clinical overlap and variability of the phenotypes, they are now considered extremities of the spectrum of a single disease, named ARCI (3).
The genetic background of ARCI consists of mutations in 9 genes: TGM1, encoding transglutaminase 1 (TGase1), an enzyme mandatory for cornified envelope formation, and 8 other genes encoding proteins involved in lipid transport and secretion of lamellar bodies (ABCA12) or the metabolic pathways of fatty acids, triglycerides and ceramides (ALOX12B, ALOXE3, NIPAL4, CYP4F22, LIPN, PNPLA1 and CERS3) (4). Although NIPAL4 (NIPA like domain containing 4) was identified in 2004 (5), the physiological role of the membrane associated protein ichthyin - frequently found in skin and other organs - is still not clear. Recently it has been considered a magnesium transporter (6), probably of fatty acid transporter protein 4 (FATP4) in the epidermal lipid processing cascade (7).

A large study found NIPAL4 mutations in $16 \%$ of ARCI patients, second only to TGM1 defects (8), with 10 different NIPAL4 mutations described in 39 families of various origins worldwide: c. $403 \mathrm{C}>\mathrm{A}, \quad \mathrm{c} .425 \mathrm{G}>\mathrm{T}$, 
c. $433 \mathrm{C}>\mathrm{T}$, c. $464-1 \mathrm{G}>\mathrm{A}$, c. $527 \mathrm{C}>\mathrm{A}$, c. $623 \mathrm{C}>\mathrm{T}$, c. $688 \mathrm{G}>\mathrm{A}, \quad$ c. $709 \mathrm{C}>\mathrm{G}, \quad$ c. $772+1 \mathrm{G}>\mathrm{A}$ and c. $889 \mathrm{G}>\mathrm{A}(5,9-13)$.

This report presents clinical particularities of 3 Romanian ARCI patients with NIPAL4 mutation, highlighting histological and ultrastructural findings, and TGase 1 activity assay results.

\section{Material and methods}

Three Caucasian ARCI patients were investigated: P1 and P2 -sisters, aged 47 and 49 years, respectively - and an unrelated female patient P3, aged 42. None had a history of other skin anomalies or consanguinity in their families. The study was a case series approved by the local Ethics Committee and performed according to the World Medical Association Declaration of Helsinki, revised in 2000, Edinburgh, with informed consent from all subjects.

Specific traits of the skin disease were recorded and documented photographically. Peripheral blood samples $(6 \mathrm{ml})$ were harvested for DNA extraction and gene analysis; skin biopsies (3-4 mm) were used for histological assessment, electron microscopy, and evaluation of in situ TGase1 activity. Normal skin and peripheral blood samples from 3 patients without ichthyosis were used as controls.

TGase1 assay in skin samples: The TGase1 in situ activity assay was performed as previously described (14). Shock frozen skin biopsies were incubated using biotinylated cadaverine (Molecular Probes, Leiden, the Netherlands), in the presence of $\mathrm{Ca} 2+$ and a controlled $\mathrm{pH}$ (7.4), promoting covalent incorporation of the biotinylated substrate in the cornified envelope almost exclusively by TGase1. Slides incubated with fluorocrome coupled streptavidin 1:100 (Jackson ImmunoResearch Laboratories Inc., West Groove, PA, USA) and assessed with an Olympus BX41TF fluorescence microscope (U-LH$100 \mathrm{HG}$, Olympus, Japan).
Transmission electron and light microscopy: Skin biopsies were prefixed with $2.7 \%$ glutaraldehyde, postfixed with $1 \%$ osmium tetroxide, dehydrated in acetone series, and embedded in Epon 812. Ultrathin sections of 70-80 nm obtained on a Bromma 8800 Ultratome III (LKB, Sweden) were taken on copper grids (mesh 200), contrasted with uranyl acetate and lead citrate, and examined using a Jeol JEM 1010 transmission electron microscope (Jeol, Tokyo, Japan), to establish ultrastructural type (I-IV).

For histological assessment, skin samples were prepared and stained with hematoxylin and eosin (HE) according to the usual protocol of the laboratory.

Sequence analysis: Genomic DNA was extracted from whole peripheral blood of patients and controls using the QIAamp DNA blood midi kit (Qiagen, Hilden, Germany). The entire NIPAL4 gene (NM_001099287.1) all exons independently, including all intron-exon boundaries, was amplified by polymerase chain reaction (Touch-Down $65-55^{\circ} \mathrm{C} \mathrm{PCR}$ under the following conditions $95^{\circ} \mathrm{C}$ $3 \mathrm{~min}+10 \mathrm{X}\left(95^{\circ} \mathrm{C} 30 \mathrm{~s}+\mathrm{TD} 65-55^{\circ} \mathrm{C} 30 \mathrm{~s}+72^{\circ} \mathrm{C}\right.$ $30 \mathrm{~s})+30 \mathrm{X}\left(95^{\circ} \mathrm{C} 30 \mathrm{~s}+55^{\circ} \mathrm{C} 30 \mathrm{~s}+72^{\circ} \mathrm{C} 30 \mathrm{~s}\right)$ $\left.+72^{\circ} \mathrm{C} 7 \mathrm{~min}+4^{\circ} \mathrm{C} \infty\right)$. Specific $20-21$ nucleotide forward and reverse sequencing primers were used for each of the 6 exons of the gene (table 1). The Sanger method was used for sequencing, with a 3130 XL Applied Biosystems Genetic Analyser (Applied Biosystems, Foster City, CA, USA).

\section{Results}

Clinical assessment: All patients presented generalized ichthyosis, with characteristics described in Table 1. Patients 1 and 2 presented fine generalised whitish scaling on an erythematous background (more intense in P1), with larger scales on the legs. In P3 generalized yellowish lamellar adherent scales and reticulated brownish ichthyosis were present on the trunk, associating very mild erythroderma. 
Only P1 had a collodion membrane at birth, while P2 developed CIE soon after birth, and P3 had yellow cracked skin at birth, developing LI later on. Palmoplantar keratoderma was present in all patients (mild form in P3), showing a yellowish hue in P1 and P2 that was more severe in $\mathrm{P} 1$; the latter also showed nail clubbing and mild deformity of the hands, and partial func-

Table 1. Clinical and paraclinical characteristics of the patients (CIE = congenital erythroderma, $\mathrm{LI}=$ lamellar ichthyosis) and the forward and reverse sequencing primers used for each of the 6 exons of NIPAL4.

\begin{tabular}{|c|c|c|c|c|}
\hline \multicolumn{2}{|c|}{ Characteristics } & Patient 1 & Patient 2 & Patient 3 \\
\hline \multicolumn{2}{|c|}{ Gender } & $\mathrm{F}$ & $\mathrm{F}$ & $\mathrm{F}$ \\
\hline \multicolumn{2}{|l|}{ Age } & 47 & 49 & 42 \\
\hline \multicolumn{2}{|c|}{ Collodion baby } & Yes & No & No \\
\hline \multicolumn{2}{|c|}{ Phenotype } & CIE & $\mathrm{CIE}$ & LI \\
\hline \multicolumn{2}{|c|}{ Palmar-plantar keratoderma } & Present & Present & Present \\
\hline \multicolumn{2}{|c|}{ Hyperlinearity } & Absent & Absent & Absent \\
\hline \multicolumn{2}{|c|}{ Ectropion } & Present & Present & Absent \\
\hline \multicolumn{2}{|c|}{ Alopecia } & Present & Absent & Absent \\
\hline \multicolumn{2}{|c|}{ Ear cartilage hypoplasia } & Present & Absent & Absent \\
\hline \multicolumn{2}{|c|}{ Hypohidrosis } & Present & Present & Absent \\
\hline \multicolumn{2}{|c|}{ Pruritus } & Present & Absent & Absent \\
\hline \multicolumn{2}{|c|}{ Skin sample TGase 1 in situ assay } & Positive & Positive & Positive \\
\hline \multicolumn{2}{|c|}{$\begin{array}{l}\text { Ultrastructural type (electron } \\
\text { microscopy) }\end{array}$} & I, III & I, III & I, III \\
\hline \multicolumn{2}{|c|}{ NIPAL4 mutation } & E4: c. $[527 \mathrm{C}>\mathrm{A}]$ & E4: c. $[527 \mathrm{C}>\mathrm{A}]$ & E4: c. $[527 \mathrm{C}>\mathrm{A}]$ \\
\hline Exon & $\begin{array}{l}\text { Length } \\
\text { (bp) }\end{array}$ & Forward sequence & Reverse sequence & Analysed region \\
\hline 1 & NIPAL4-E1D/R 701 & $\begin{array}{l}\text { TTTCCCTGGG- } \\
\text { GATGGAGCTG }\end{array}$ & $\begin{array}{l}\text { TGCTGTCGTCAAAA } \\
\text { TGCCTG }\end{array}$ & $\begin{array}{l}\text { c. }-82- \\
116 \_ \text {c. } 223+280\end{array}$ \\
\hline 2 & NIPAL4-E2D/R 507 & $\begin{array}{l}\text { GTGGAGGCACG- } \\
\text { GTATATGGG }\end{array}$ & $\begin{array}{l}\text { GGCAGGTGGGATTCC } \\
\text { AGATAG }\end{array}$ & $\begin{array}{l}\text { c. } 224- \\
132 \_c .463+135\end{array}$ \\
\hline 3 & NIPAL4-E3D/R 256 & $\begin{array}{l}\text { GAACCAAGCCT- } \\
\text { CAAGGAGCA }\end{array}$ & $\begin{array}{l}\text { AAAAATGCCCTACCC } \\
\text { ACCCC }\end{array}$ & $\begin{array}{l}\text { c. } 464- \\
116 \_c .520+83\end{array}$ \\
\hline 4 & NIPAL4-E4D/R 239 & $\begin{array}{l}\text { GTCTGGAATG- } \\
\text { GAGATGGTGCT }\end{array}$ & $\begin{array}{l}\text { GTGGCAGTCGATCCC } \\
\text { ACTTG }\end{array}$ & $\begin{array}{l}\text { c. } 521- \\
61 \_c .611+87 \\
\end{array}$ \\
\hline 5 & NIPAL4-E5D/R 402 & $\begin{array}{l}\text { TTGCT- } \\
\text { CAGGCCCCAT- } \\
\text { TTTCTT }\end{array}$ & $\begin{array}{l}\text { GCCTTGCTAACAAGTA } \\
\text { CCAGC }\end{array}$ & $\begin{array}{l}\text { c. } 612- \\
78 \_c .772+163\end{array}$ \\
\hline 6 & NIPAL4-E6D/R 812 & $\begin{array}{l}\text { CTCCCACTGC- } \\
\text { CATGAGTCTG }\end{array}$ & $\begin{array}{l}\text { GCCCATTGGTAACAG } \\
\text { TTGCAC }\end{array}$ & $\begin{array}{l}\text { c. } 773- \\
81 \_.1401+102\end{array}$ \\
\hline
\end{tabular}


tional impotence due to painful fissures in lack of continuous local treatment.

Ectropion was noted in $\mathrm{P} 1$ and $\mathrm{P} 2$, with a more severe form in $\mathrm{P} 1$, requiring constant use of artificial tears. All patients had normal hair shafts, but P1 reported cicatricial alopecia starting in adolescence. Both P1 and P2 presented hypohidrosis and complained of an important reduction in heat and effort tolerance, with $\mathrm{P} 1$ only sweating on the upper lip and glabella, and P2 reporting facial sweating and reduced axillar and inguinal sweating.

Pruritus was present in P1 and it was related to overheating; this had been more intense in childhood, on exertion, and when in a warm environment, although laboratory findings showed normal IgE levels. Significant oral manifestations were present in all patients, with multiple
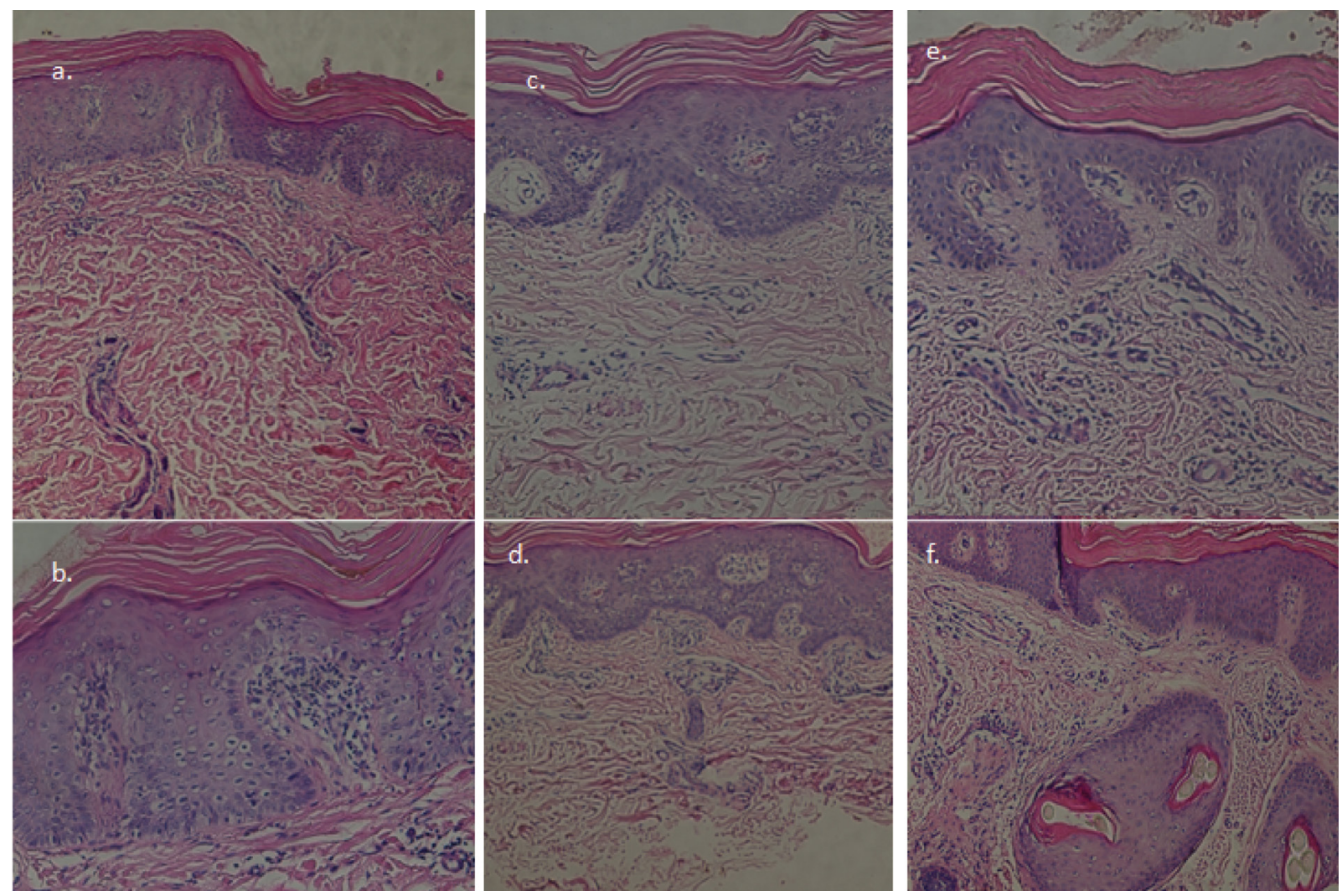

Figure 1. P1 (a, b): hyperkeratosis and acanthosis with follicular plugging; epidermal squamous cell layer thickening, with several layers of polygonal cells with eosinophilic cytoplasm, round, central nuclei, well developed nucleoli; continuous granular layer consisting of flattened cells, with cytoplasm and nucleus masked by basophilic granules of keratohyalin; thickened stratum corneum, consisting of eosinophilic lamellae; irregular dermal papillae; sweat glands and dilated blood vessels in the dermis, with abundant lymphoplasmacytic infiltrate in the dermal papillae and perivascularly. P2 (c, d): similar to P1, with hyperkeratosis, well developed, acanthotic stratum corneum, moderate lymphoplasmacytic infiltrate perivascularly and in the dermal papillae. P3 (e, f): Similar to P1 and P2, but with marked hyperkeratosis, more severe irregularities of the dermal papillae, discontinuous granular layer, very thick, acanthotic stratum corneum, predominantly perivascular moderate chronic inflammatory infiltrate. 
caries, artificial crowns, dental bridges, and partially edentulous arches.

Natural evolution was relatively stable in all cases, without phenotype changing. Medical treatment was conducted using retinoids for P1 and P2 - etretinate and acitretin at approximately $0.5 \mathrm{mg} / \mathrm{kg}$ body weight, for around 5 years, with very favourable results and only short discontinuous periods. However, medication was subsequently stopped over a period of 15 years, due to complaints of multiple arthralgia. When treatment restarted with $25 \mathrm{mg}$ acitretin/ day, P2 showed a spectacular normalisation of her skin condition in approximately 6 weeks (no scaling or erythema), while P1 still presented mild re- sidual erythroderma, but no scaling and pruritus. Hypohidrosis was partially improved in P1 with supplementary sweating in the lumbar area, while in P2 the symptom completely disappeared. Additionally, regular use of emollients and keratolytics was mandatory for both P1 and P2.

Although P3 had a more severe skin condition in childhood, currently she was undergoing no specific medical treatment for ichthyosis, except for the use of emollients and baths 2-3 times/ week, with significant symptom improvement during summer months.

Histology: Samples showed hyperkeratosis, acanthosis (emphasized with follicular plugging in P3) and the presence of the granular layer in
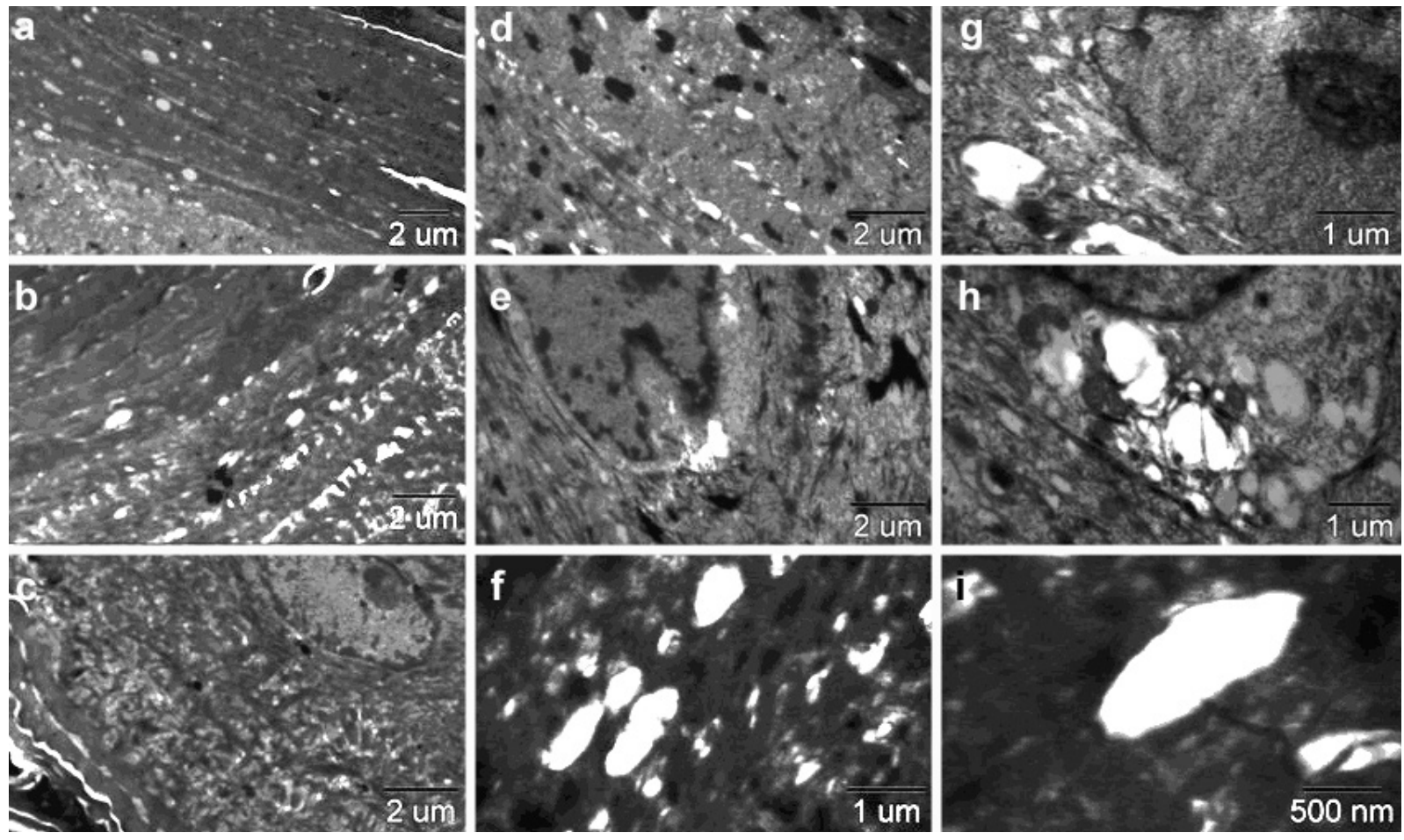

Figure 2. Electronmicrographs of the epidermis showing thickened stratum corneum and corneocytes filled with round-shaped electron transparent structures (lipid droplets) in P1 (a), in contrast to the more compact aspect of stratum corneum in P3 (b) and the normal aspect of the epidermis in a control (c). Stratum granulosum with many electron-dense granules of various shapes and sizes in the keratinocytes in P1 (d), P2 (e) and P3 (f) - probably filaggrin and NIPAL4 aggregates. The main diagnostic feature: numerous large vesicles containing several smaller vesicles in the granular layer of P1 (g), P2 (h) and P3 (f). Detailed view of a large vesicle from P3 (i). 
all patients (Figure 1). Patients 2 and 3 had a mild inflammatory infiltrate in the dermis around dilated vessels, while P1 had very abundant inflammatory infiltrate. All patients presented sweat glands.

In situ TGase1 activity: TGM1 deficiency was excluded by the positive findings of TGase 1 in situ activity. For P1 and P2 the fluorescence pattern included 6-7 layers of the stratum granulosum, while in $\mathrm{P} 3$ and controls it was present only at the periphery of cells from 2-3 layers of the stratum granulosum.

Electron microscopy: The stratum corneum consisted of over 40 layers of corneocytes, and in patients with CIE (P1 and P2) these were filled with abundant round-shaped electron-transparent structures, probably accumulations of lipid droplets (Figure 2), with the aspect of type I congenital ichtyosis. In the
LI phenotype (P3), the stratum corneum was more compact, with rare round-shape electron-transparent structures. All cases presented less distinct transition between the stratum corneum and granulosum compared to controls, with many electron-dense granules of various shapes and sizes in the keratinocytes of the stratum granulosum. The granular layer had a vesicular appearance, characteristic for type III congenital ichtyosis: numerous large vesicles containing several smaller vesicles. Peri-nuclear membranes were not clearly observable in the granular layer cells, except for one slide from P3.

Gene sequencing: In all cases, direct sequencing of the amplicons revealed one homozygous variant in exon 4 , a c. $527 \mathrm{C}>\mathrm{A}$ missense mutation resulting in Alanine-to-Aspartic acid substitution (p.Ala176Asp) (Figure 3).

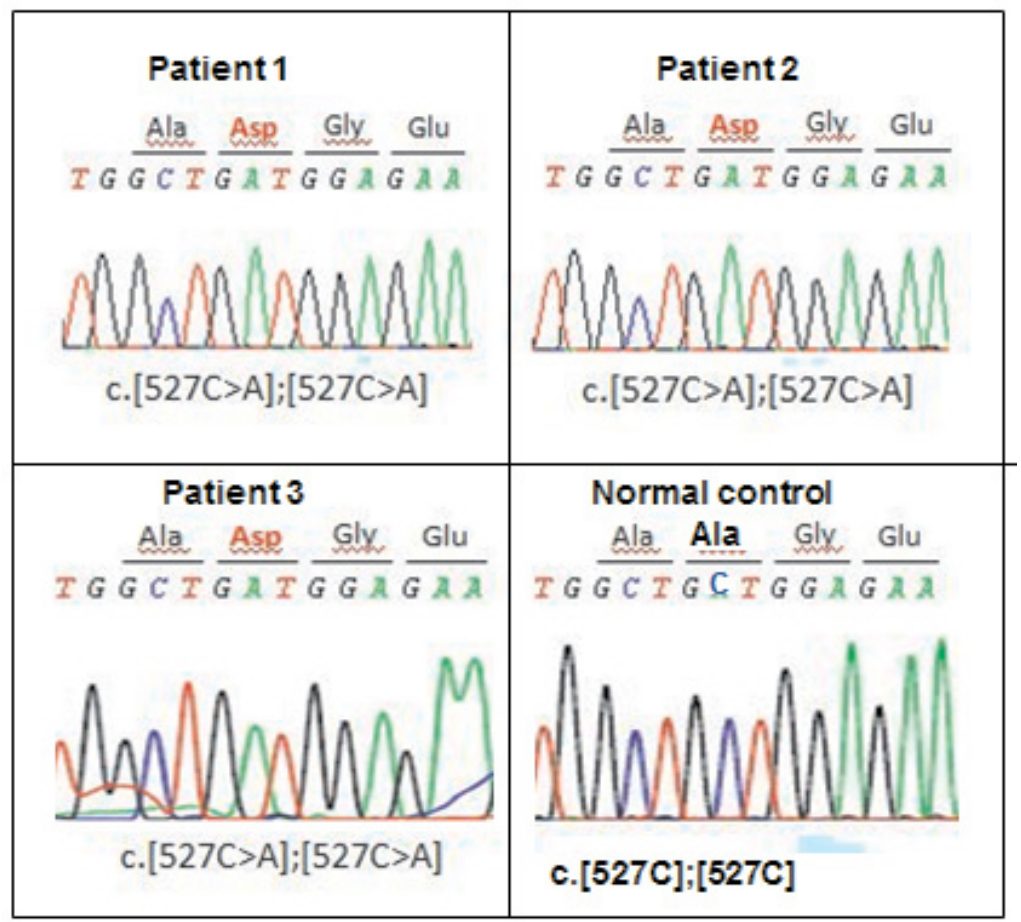

Figure 3. Sequencing of NIPAL4 revealed a homozygous $C>A$ substitution at cDNA position 527 in patients 1, 2 and 3 . The normal control is showed in the last position. 


\section{Discussions}

We present the first identification of the NIPAL4 missense mutation c.527C $>$ A (p.Ala176Asp) in Romanian ARCI patients. This was also the most frequently identified NIPAL4 mutation in ARCI patients of diverse ethnic origins, accounting for approximately $2 / 3$ of NIPAL4 mutated alleles $(5,9,10)$, and thus suggesting the existence of a possible hotspot $(9,10)$. The phenotype of our patients was similar to that reported in the literature for other patients with NIPAL4 mutations $(5,9-13)$. The mild intra-familial variation of phenotype severity between patients $\mathrm{P} 1$ and $\mathrm{P} 2$ was opposed to the results of Alavi et al. (12). However, inter-familial phenotype variation was marked, a result similar to literature data $(5,9)$. Only one of the patients presented a whole series of clinical ARCI traits reported in NIPAL4 mutations (association of collodion membrane at birth, childhood pruritus, alopecia, hypohydrosis, ectropion, nail clubbing, and reticular brownish hyperkeratosis) while yellowish palmoplantar keratoderma without hyperlinearity was constantly present in all cases. Fischer et al. consider palmoplantar findings such as keratoderma and hyperliniarity, as important clues for diagnostic orientation in ARCI patients (8). Of these, palmoplantar keratoderma is a constant feature of ARCI patients with NIPAL4 mutations, while the yellowish hue and absence of hyperlinearity are considered highly suggestive of the presence of a NIPAL4 mutation (12).

Anhidrosis or hypohidrosis is one of the most troublesome problems for ARCI patients, as it might associate heat intolerance, fatigue and erythroderma aggravation when in a hot environment (8). Two of our patients ( $\mathrm{P} 1$ and $\mathrm{P} 2$ ) presented this symptom, which seems to be a frequent find in patients with NIPAL4 mutations, or mutations of TGM 1, ALOX12B, and ALOXE3, and in some cases requires retinoid therapy (1517). Given that anhidrosis is frequently seen in mild cases of ichthyosis, where it might show a tendency for self-improving, it is considered that gland suppression is not related to the degree of disease severity (18).

Pruritus in ARCI is rare, especially the more severe manifestation in childhood; when present, pruritus is sometimes considered an overlap with atopic dermatitis (10). However, P1 reported having severe childhood pruritus, in spite of previously detected normal levels of IgE and no filaggrin defects found on ultrastructural analysis of skin biopsies. In this case, pruritus might be caused by the irritant effect of entrapped sweat in the epidermis, given that children are more prone to thermo-regulatory imbalances when exposed to higher temperatures. The gradual decrease of pruritus intensity and frequency over time is probably explained by the patient's better adapting of her activities and clothing to environmental conditions.

Usually, ARCI patients with NIPAL4 mutations respond particularly well to retinoid treatment (19) - this was the case in P1 and P2, who received the same dosage of a second generation retinoid with excellent results: skin condition was fully restored in P2 (general aspect and sweating capacity became similar to the healthy elder sister), while in P1 scaling was normalized, pruritus decreased, supplementary sweating appeared on the lower back, with only mild erythroderma. Incomplete treatment response in $\mathrm{P} 1$ might be explained by the severity of the disease (collodion baby, most severe phenotype as adult) or perhaps an inadequate dosage of retinoid.

An interesting aspect in NIPAL4 mutated ARCI patients is the oral involvement, which we described in the 2 patients previously reported (11). Extensive teeth destruction and caries were present in the 3 patients from the current study, with subsequent partial edentation, possibly due to the implication of NIPAL4 in the regulation 
of magnesium levels in enamel, an interesting hypothesis for future studies (20).

Although all 3 patients were bearing the same mutation, histological, ultrastructural and TGase 1 activity particularities were similar in patients with the same phenotype (P1, P2), but differed from those of P3. Histological examination did not offer clues for orienting genetic diagnosis, as the main feature was the presence of a granular layer. Based on TGase1 in situ activity assay, a TGM1 defect was excluded in all cases. However, there were differences in the amount of fluorescence found, with and enhanced activity identified in erythrodermic patients. This might be a compensatory mechanism for the malfunctions of the stratum corneum, as suggested by Li et al. (21) who found increased immunofluorescence staining for TGase1 in skin specimens from NIPAL4 mutated patients compared to controls.

Skin samples from CIE patients (P1 and P2) showed a non-specific pattern of electron-transparent structures classified as type I - also common in other genetic defects of CIE patients (TGM 1, lipoxygenase, etc.) (22) -, and different from the findings in the LI phenotype (P3). The granular layer was similar in all patients, with multiple electron-dense granules of various shapes and sizes in the keratinocytes, considered aggregates of filaggrin/ ichtyin. Ichthyin has been shown to have a tendency towards aggregation and accumulation in the cytoplasm of granular cells in cases of missense mutation (23). The main common abnormal feature of the granular layer in NIPAL4 mutated patients is the presence of numerous large vesicles containing smaller vesicles, probably representing defective lamellar bodies. It has been suggested that ichthyin might influence the formation and transport of lamellar bodies and is therefore present in the majority of patients with NIPAL4 mutations (9). Another important characteristic of type III congenital ichtyiosis, significantly correlated with NIPAL4 mutations (9), is the presence of perinuclear membranes in granular layer cells; this was not clear in our samples except for one slide of P3, although over 100 slides were analysed for each patient.

The importance of the study is given by the fact that it increases the number of NIPAL4 mutations identified in Romanian ARCI patients. The 3 patients presented here were also part of a study on TGase1 deficiency that included 18 Romanian ARCI patients (24), of which we previously reported 2 other patients with a different new NIPAL4 mutation (11). Thus the total number of cases identified with NIPAL4 mutations was 5 out of 18 ; furthermore, only 3 cases of TGM1 mutations were found. Although sequencing for the rest of the patients is still in progress, our results so far indicate that NIPAL4 mutations appear to be more frequent than TGM1 mutations in Romanian ARCI patients. In light the of this information, we consider NIPAL4 mutations as a major cause of ARCI in the Romanian population. This is in contrast with the low frequency/ absence of NIPAL4 mutations reported in ARCI patients from Israel and Spain, as well as with the results of a larger study conducted on various populations which found fewer NIPAL4 mutations compared to those of TGM1 $(8,13,25)$.

The limitations of the study are mainly due to the low number of patients identified with the specific NIPAL4 mutation, hindering proper statistical analysis of clinical and imagistic features.

\section{Conclusions}

This is the first report of the hotspot mutation NIPAL4 c.527C $>$ A in Romanian ARCI patients. Although we identified no supplementary clues for NIPAL4 mutations in these patients compared to those presented in the literature, we did detect differences in TGasel enzyme distribution and 
electron microscopic characteristics between patients bearing the same mutation. Interestingly, both patterns were similar for the two patients with the CIE phenotype. This relationship between clinical, histological, ultrastructural, and genetic features is detailed for the first time in this category of patients.

Our results support previous data on Romanian ARCI patients, highlighting the importance of NIPAL4 sequencing in these cases, as NIPAL4 mutation probably represents a major cause of ARCI in Romanian patients.

\section{Acknowledgments}

We express our gratitude and many thanks to Professor Dr. Juliette Mazereeuw-Hautier from the Service de Dermatologie, Centre de Référence des Maladies Rares de la Peau, Hôpital Larrey, Toulouse, France and Associate professor Dr. Nathalie Jonca who works together with Prof. Mazereeuw-Hautier at the UMR 5165/ U1056 "Différenciation Epidermique et Autoimmunité Rhumatoïde“, CNRS-1056, INSERM - Université Toulouse III, Hôpital Purpan, Toulouse, France for their kind help and for genotyping the patients. We would also like to thank the patients participating in the study, and the Romanian Association for Congenital Ichthyosis and Related Disorders.

\section{The authors report no conflict of interest. The study had no sources of funding.}

\section{List of abbreviations}

$\begin{array}{ll}\text { ARCI } & =\text { autosomal recessive congenital } \\ & \text { ichthyosis } \\ \text { CIE } & =\text { congenital erythroderma } \\ \text { FATP4 } & =\text { fatty acid transporter protein } \\ \text { HE } & =\text { hematoxylin and eosin } \\ \text { LI } & =\text { lamellar ichthyosis } \\ \text { TGase1 } & =\text { transglutaminase } 1\end{array}$

\section{References}

1. Dreyfus I, Chouquet C, Ezzedine K, Henner S, Chiaverini C, Maza A, et al. Prevalence of inherited ichthyosis in France: a study using capture-recapture method. Orphanet J Rare Dis. 2014;9:1. DOI: 10.1186/1750-1172-9-1.

2. Oji V, Tadini G, Akiyama M, Blanchet Bardon C, Bodemer C, Bourrat E, et al. Revised nomenclature and classification of inherited ichthyoses: results of the First Ichthyosis Consensus Conference in Soreze 2009. J Am Acad Dermatol. 2010;63(4):607-41. DOI: 10.1016/j. jaad.2009.11.020.

3. Akiyama M, Sawamura D, Shimizu H. The clinical spectrum of nonbullous congenital ichthyosiform erythroderma and lamellar ichthyosis. Clin Exp Dermatol. 2003;28(3):235-40. DOI: 10.1046/j.13652230.2003.01295.x.

4. Traupe H, Fischer J, Oji V. Nonsyndromic types of ichthyoses - an update. J Dtsch Dermatol Ges. 2014;12(2):109-21. DOI: 10.1111/ddg.12229 DOI: 10.1111/ddg.12229_suppl.

5. Lefevre C, Bouadjar B, Karaduman A, Jobard F, Saker S, Ozguc M, et al. Mutations in ichthyin a new gene on chromosome $5 \mathrm{q} 33$ in a new form of autosomal recessive congenital ichthyosis. Hum Mol Genet. 2004;13(20):2473-82. DOI: $10.1093 / \mathrm{hmg} /$ ddh 263 .

6. Quamme GA. Molecular identification of ancient and modern mammalian magnesium transporters. Am J Physiol Cell Physiol. 2010;298(3):C407-29. DOI: 10.1152/ajpcell.00124.2009.

7. Li H, Vahlquist A, Torma H. Interactions between FATP4 and ichthyin in epidermal lipid processing may provide clues to the pathogenesis of autosomal recessive congenital ichthyosis. J Dermatol Sci. 2013;69(3):195-201. DOI: 10.1016/j.jdermsci.2012.11.593.

8. Fischer J. Autosomal recessive congenital ichthyosis. J Invest Dermatol. 2009;129(6):1319-21. DOI: 10.1038/ jid.2009.57.

9. Dahlqvist J, Klar J, Hausser I, Anton-Lamprecht I, Pigg MH, Gedde-Dahl T, Jr., et al. Congenital ichthyosis: mutations in ichthyin are associated with specific structural abnormalities in the granular layer of epidermis. J Med Genet. 2007;44(10):615-20. DOI: 10.1136/ jmg.2007.050542. 
10. Wajid M, Kurban M, Shimomura Y, Christiano AM. NIPAL4/ichthyin is expressed in the granular layer of human epidermis and mutated in two Pakistani families with autosomal recessive ichthyosis. Dermatology. 2010;220(1):8-14. DOI: 10.1159/000265757.

11. Maier D, Mazereeuw-Hautier J, Tilinca M, Cosgarea $\mathrm{R}$, Jonca N. Novel mutation in NIPAL4 in a Romanian family with autosomal recessive congenital ichthyosis. Clin Exp Dermatol. 2016 Apr;41(3):279-82.

12. Alavi A, Shahshahani MM, Klotzle B, Fan JB, Ronaghi M, Elahi E. Manifestation of diffuse yellowish keratoderma on the palms and soles in autosomal recessive congenital ichthyosis patients may be indicative of mutations in NIPAL4. The Journal of dermatology. 2012;39(4):375-81. DOI: 10.1111/j.13468138.2011.01412.x.

13. Israeli S, Goldberg I, Fuchs-Telem D, Bergman $\mathrm{R}$, Indelman $\mathrm{M}$, Bitterman-Deutsch $\mathrm{O}$, et al. Nonsyndromic autosomal recessive congenital ichthyosis in the Israeli population. Clin Exp Dermatol. 2013;38(8):911-6. DOI: 10.1111/ced.12148.

14. Raghunath M, Hennies HC, Ahvazi B, Vogel M, Reis A, Steinert PM, et al. Self-healing collodion baby: a dynamic phenotype explained by a particular transglutaminase-1 mutation. J Invest Dermatol. 2003;120(2):2248. DOI: $10.1046 /$ j.1523-1747.2003.12032.x.

15. Farasat S, Wei MH, Herman M, Liewehr DJ, Steinberg SM, Bale SJ, et al. Novel transglutaminase-1 mutations and genotype-phenotype investigations of 104 patients with autosomal recessive congenital ichthyosis in the USA. J Med Genet. 2009;46(2):103-11. DOI: 10.1136/ jmg.2008.060905.

16. Eckl KM, de Juanes S, Kurtenbach J, Natebus M, Lugassy J, Oji V, et al. Molecular analysis of 250 patients with autosomal recessive congenital ichthyosis: evidence for mutation hotspots in ALOXE3 and allelic heterogeneity in ALOX12B. J Invest Dermatol. 2009;129(6):1421-8. DOI: 10.1038/jid.2008.409.

17. Haenssle HA, Finkenrath A, Hausser I, Oji V, Traupe $\mathrm{H}$, Hennies $\mathrm{HC}$, et al. Effective treatment of severe thermodysregulation by oral retinoids in a patient with recessive congenital lamellar ichthyosis. Clin Exp Dermatol. 2008;33(5):578-81. DOI: 10.1111/j.13652230.2008.02709.x.
18. Vahlquist A, Bygum A, Ganemo A, Virtanen M, Hellstrom-Pigg M, Strauss G, et al. Genotypic and clinical spectrum of self-improving collodion ichthyosis: ALOX12B, ALOXE3, and TGM1 mutations in Scandinavian patients. J Invest Dermatol. 2010;130(2):438-43. DOI: 10.1038/jid.2009.346.

19. Pavez Lorie E, Ganemo A, Borgers M, Wouters L, Blockhuys S, van de Plassche L, et al. Expression of retinoid-regulated genes in lamellar ichthyosis vs. healthy control epidermis: changes after oral treatment with liarozole. Acta Derm Venereol. 2009;89(1):12-20. DOI: $10.2340 / 00015555-0573$.

20. Halusic AM, Sepich VR, Shirley DC, Granjeiro JM, Costa MC, Kuchler EC, et al. Calcium and magnesium levels in primary tooth enamel and genetic variation in enamel formation genes. Pediatr Dent. 2014;36(5):384-8.

21. Li H, Lorie EP, Fischer J, Vahlquist A, Torma H. The expression of epidermal lipoxygenases and transglutaminase-1 is perturbed by NIPAL4 mutations: indications of a common metabolic pathway essential for skin barrier homeostasis. J Invest Dermatol. 2012;132(10):2368-75. DOI: 10.1038/jid.2012.160.

22. Pigg M, Gedde-Dahl T, Jr., Cox D, Hausser I, AntonLamprecht I, Dahl N. Strong founder effect for a transglutaminase 1 gene mutation in lamellar ichthyosis and congenital ichthyosiform erythroderma from Norway. Eur J Hum Genet. 1998;6(6):589-96. DOI: 10.1038/ sj.ejhg. 5200224 .

23. Dahlqvist J, Westermark GT, Vahlquist A, Dahl N. Ichthyin/NIPAL4 localizes to keratins and desmosomes in epidermis and Ichthyin mutations affect epidermal lipid metabolism. Arch Dermatol Res. 2012;304(5):37786. DOI: $10.1007 / \mathrm{s} 00403-012-1207-7$.

24. Maier D, Tilinca M, Cosgarea R. Detection of in situ Transglutaminase 1 activity in Romanian patients with autosomal recessive congenital ichthyosis. Annals of RSCB. 2014;19(1):65-72.

25. Rodriguez-Pazos L, Ginarte M, Fachal L, Toribio J, Carracedo A, Vega A. Analysis of TGM1, ALOX12B, ALOXE3, NIPAL4 and CYP4F22 in autosomal recessive congenital ichthyosis from Galicia (NW Spain): evidence of founder effects. Br J Dermatol. 2011;165(4):906-11. DOI: $10.1111 /$ j.13652133.2011.10454.x. 
